\title{
Medical evacuations among offshore oil and gas industries in the Gulf of Thailand
}

\author{
Thanawat Sae-Jia ${ }^{1,2} \mathbb{D}$, Pornchai Sithisarankul ${ }^{1} \mathbb{D}$ \\ ${ }^{1}$ Department of Preventive and Social Medicine, Faculty of Medicine, Chulalongkorn University, Bangkok, Thailand \\ ${ }^{2}$ Maritime Medicine Residency Training Institute, Naval Medical Department, Royal Thai Navy, Bangkok, Thailand
}

\begin{abstract}
Background: Medical evacuation in the offshore oil and gas industry is costly and risky. Previous studies have found that the main cause of medical evacuation due to illness is increasing. In Thailand, there have been no studies on the causes and costs of medical evacuation in the offshore oil and gas industry. This study aims to study on the causes and costs of medical evacuation among offshore oil and gas industry in the Gulf of Thailand.

Materials and methods: A retrospective review of data of medical evacuation among the offshore oil and gas industry in the Gulf of Thailand from 2016 to 2019 for a period of 36 months.

Results: During the research period, a total of 416 cases were evacuated. The majority of the causes of Medevac (84.13\%) were illness. We found that $60.1 \%$ of all Medevacs were unpreventable or difficult to prevent, and only 39.9\% were preventable. The cost of Medevac ranged from 10,000 to 880,000 THB per case. The cost of Medevac occurring from preventable causes was 17,160,000 THB for this period of 36 months.

Conclusions: Reducing the cost of Medevac can be done by: 1) vaccination to prevent vaccine-preventable diseases, 2) screening to prevent people at risk of getting complications from pre-existing diseases to work offshore, and 3) increasing treatment capability of offshore facilities. Offshore oil and gas industry may consider cost-benefit of these approaches compared to status quo.
\end{abstract}

(Int Marit Health 2020; 71, 2: 114-122)

Key words: medical evacuation, Medevacs, oil and gas industry, offshore

\section{INTRODUCTION}

Operations in the offshore oil and gas industry are operations in special areas. Workers often work under environments different from general establishments. They usually work offshore for 14 consecutive days with shifts, alternate with staying onshore for 28 days (may vary depending on the agency and job position). They have a risk of personal health problems and work safety with the condition of the job at risk both from variable weather and accidents that may occur from working with machines [1]. Including unpreventable illnesses such as acute appendicitis or acute myocardial infarction.

In general, offshore rigs and platforms have medical personnel who can provide initial treatment to workers when the illness occurs. However, only some treatment can be pro- vided due to remoteness and lack of sophisticated medical equipment. Some may seek medical consultation through a remote medical system (telemedicine) [2, 3].

In each offshore facility, there are medics on board for $24 \times 7$ services but there may not be a doctor at all times. The doctor is usually on a large platform and also takes care of other small platforms nearby. The facility clinic can handle illnesses/injuries of the medical treatment scope. Beyond this scope, the decision of referral is made by the on-duty doctor. The facility clinic has some life-saving medicines, isolation units, full personal protective equipment and protocol for infectious cases handling, can cast/external immobilisation for closed fracture, can do wound suturing/cleaning, but does not have general anaesthesia, operating room, nor negative pressure room.

Thanawat Sae-Jia, MD, Maritime Medicine Residency Training Institute, Naval Medical Department, Thailand, e-mail: thanawatsj@gmail.com 
If a serious illness or accident occurs and exceeds the offshore medical treatment capability, that victim requires to be moved to an appropriate, usually onshore, hospital. This is done via an aircraft or a boat and often beyond regular schedule, thus increases the cost and the risk, especially in bad weather. Therefore, such medical evacuation is seriously considered regarding its severity and emergency [2].

In Thailand, there have been no studies on the causes and costs of medical evacuation in the offshore oil and gas industry. This study aims to investigate the causes and costs of medical evacuation among the offshore oil and gas industry in the Gulf of Thailand.

\section{MATERIALS AND METHODS}

This study was a retrospective descriptive study. The study was conducted using a previous medical record of medical evacuation among the offshore oil and gas industry in the Gulf of Thailand, which is a secondary data obtained from companies that consent to disclose information excluding names of companies and victims due to non-disclosure agreement. Such data were usually kept for 36 months then deleted. For this study, we obtained data of April 2016 to March 2019.

The data collection included demographic data (age, gender, nationality, type of employment, underlying disease) and diagnosis before and after Medevac (initial and final diagnosis). Then, we classified as injury or illness, and preventable or unpreventable/difficult to prevent. We calculated and compared the costs caused by preventable or unpreventable/difficult to prevent, and suggested methods for prevention. The estimated cost of evacuation was presented as a lump sum price per time and the detail was distributed as cost per flight time, doctor and nurse fee and other expenses.

\section{STATISTICAL ANALYSIS}

Data analysis was performed using STATA version 14.0 (StataCorp. 2015. Stata Statistical Software: Release 14.1. College Station, TX: StataCorp LLC). Variables with normal distribution were presented as mean (standard deviation [SD]) and those with non-normal distribution were presented as median (interquartile range [IQR]). Qualitative variables were presented with counts and percentages.

After obtaining approval from the Ethics Committee of the Faculty of Medicine, Chulalongkorn University, and obtaining companies' consent to disclose information, the study was conducted in the second week of June 2019.

\section{RESULTS}

From April 2016 to March 2019, there were a total of 416 evacuated cases, 410 (98.56\%) males and 6 (1.44\%) females; the median age was 37 years. Forty-seven per cent of the patients were between the ages of 30 to 39 . The majority of the evacuees were 376 Thais (90.38\%), followed by American 7 (1.6\%) cases. The type of employment showed that evacuees were 216 (51.92\%) subcontractors, 196 (47.12\%) direct employees and 4 (0.96\%) others (fishermen). No underlying disease data were obtained because such data were not recorded. The demographic data of the evacuees are presented in Table 1.

Other additional information received includes: types of evacuation, reasons for disembarkation, final diagnoses, outcome of treatment and work-relatedness, which is demonstrated in Table 2. Company doctor, doctor at assistance centre or offshore/rig manager decided on the need and type of medical evacuation as follows: emergency disembarking was immediate evacuation or within 24 hours

Table 1. Medevacs' demographic data

\begin{tabular}{|c|c|c|}
\hline \multirow{2}{*}{$\begin{array}{l}\begin{array}{l}\text { Demographic } \\
\text { characteristics }\end{array} \\
\text { Gender }\end{array}$} & \multicolumn{2}{|c|}{$\begin{array}{l}\text { Number and per cent } \\
\text { of Medevacs }\end{array}$} \\
\hline & & \\
\hline Male & 410 & $98.56 \%$ \\
\hline Female & 6 & $1.44 \%$ \\
\hline \multicolumn{3}{|l|}{ Age group [year] } \\
\hline$<30$ & 50 & $12.02 \%$ \\
\hline $30-39$ & 196 & $47.12 \%$ \\
\hline $40-49$ & 121 & $29.09 \%$ \\
\hline $50-59$ & 44 & $10.58 \%$ \\
\hline$>59$ & 5 & $1.2 \%$ \\
\hline \multicolumn{3}{|l|}{ Age [year] } \\
\hline Minimum & 22 & \\
\hline Median (IQR) & 37 & $13 \%$ \\
\hline Maximum & 66 & \\
\hline \multicolumn{3}{|l|}{ Nationality } \\
\hline Thai & 376 & $90.38 \%$ \\
\hline American & 7 & $1.68 \%$ \\
\hline Malaysian & 6 & $1.44 \%$ \\
\hline Indonesian & 5 & $1.20 \%$ \\
\hline Australian & 5 & $1.20 \%$ \\
\hline Canadian & 4 & $0.96 \%$ \\
\hline Filipino & 3 & $0.72 \%$ \\
\hline Myanmaese & 2 & $0.48 \%$ \\
\hline Irish & 2 & $0.48 \%$ \\
\hline Dutch & 1 & $0.24 \%$ \\
\hline Indian & 1 & $0.24 \%$ \\
\hline Laotian & 1 & $0.24 \%$ \\
\hline New Zealander & 1 & $0.24 \%$ \\
\hline Portuguese & 1 & $0.24 \%$ \\
\hline Croatian & 1 & $0.24 \%$ \\
\hline \multicolumn{3}{|c|}{ Type of employment } \\
\hline Subcontractor & 216 & $51.92 \%$ \\
\hline Direct employee & 196 & $47.12 \%$ \\
\hline Other & 4 & $0.96 \%$ \\
\hline
\end{tabular}


Table 2. Additional information

\begin{tabular}{lll}
\hline Additional information & $\begin{array}{l}\text { Number and per cent } \\
\text { of Medevacs }\end{array}$ \\
\hline Type of evacuation & & \\
Emergency disembarking & 39 & $9.38 \%$ \\
Non-emergency disembarking & 328 & $78.85 \%$ \\
Medical referral & 49 & $11.78 \%$ \\
Reasons for disembarkation & & \\
Treatment & 279 & $67.07 \%$ \\
Isolation & 122 & $29.33 \%$ \\
Investigation & 10 & $2.40 \%$ \\
Repatriation & 5 & $1.20 \%$ \\
Final diagnosis & & \\
No final diagnosis & 274 & $65.87 \%$ \\
Known final diagnosis & 142 & $34.13 \%$ \\
Outcome of treatment & & \\
Unknown or no follow up & 338 & $81.25 \%$ \\
Recovery and ready to return to work & 64 & $15.38 \%$ \\
Unfit to work offshore & 12 & $2.88 \%$ \\
Death & 2 & $0.48 \%$ \\
Work-related diseases & & $89.58 \%$ \\
Yes & 44 & \\
No & 372 & $89.4 \%$ \\
\hline
\end{tabular}

such as acute myocardial infarction. Non-emergency disembarking was evacuation within 24-72 hours such as urolithiasis or dental caries. Medical referral was evacuation for ongoing treatment, or treatment could be done offshore but the patient cannot work or can work but not fully, such as sprain and strain of ankle. Only 38 (9.13\%) of the evacuees were emergency disembarking, while most evacuees (79.08\%) were non-emergency disembarking. Regarding reasons for disembarkation, 279 evacuees (67.07\%) were evacuated for treatment. Most evacuees (65.87\%) had no final diagnoses. About $89.42 \%$ of Medevacs were not work-related diseases. Regarding outcome of treatment, $81.25 \%$ of cases were unknown outcomes or no follow-up.

\section{REASONS FOR MEDEVACS IN THE GULF OF THAILAND}

Reasons for Medevacs in the Gulf of Thailand were grouped by ICD-10 version 2016 [4] and shown in Table 3. During the research period, the majority of the causes of Medevac (diagnosis before Medevac) were diseases of the respiratory system 95 (22.84\%) cases, the majority of this group was influenza 84 cases, followed by group of Injury, poisoning and certain other consequences of external causes $64(15.38 \%)$ cases, the majority of this group was injury and wound 31 cases, certain infectious and parasitic diseases $51(12.26 \%)$ cases, the majority of this

Table 3. Reasons for Medevacs (Initial diagnosis ICD-10 group) by incident year

\begin{tabular}{|c|c|c|c|c|}
\hline \multirow[t]{2}{*}{ Initial diagnosis ICD-10 group } & \multicolumn{4}{|c|}{ Incident year } \\
\hline & $1^{\text {st }}$ & $2^{\text {nd }}$ & $3^{\text {rd }}$ & Total \\
\hline Certain infectious and parasitic diseases & 15 & 8 & 28 & 51 \\
\hline Endocrine, nutritional and metabolic diseases & 0 & 0 & 1 & 1 \\
\hline Mental and behavioural disorders & 0 & 1 & 2 & 3 \\
\hline Diseases of the nervous system & 2 & 6 & 4 & 12 \\
\hline Diseases of the eye and adnexa & 3 & 9 & 3 & 15 \\
\hline Diseases of the ear and mastoid process & 1 & 3 & 2 & 6 \\
\hline Diseases of the circulatory system & 3 & 4 & 3 & 10 \\
\hline Diseases of the respiratory system & 12 & 55 & 28 & 95 \\
\hline Diseases of the digestive system & 17 & 19 & 13 & 49 \\
\hline Diseases of the skin and subcutaneous tissue & 2 & 9 & 11 & 22 \\
\hline Diseases of the musculoskeletal system and connective tissue & 3 & 14 & 7 & 24 \\
\hline Diseases of the genitourinary system & 4 & 10 & 10 & 24 \\
\hline Pregnancy, childbirth and the puerperium & 1 & 1 & 0 & 2 \\
\hline Congenital malformations, deformations and chromosomal abnormalities & 0 & 0 & 0 & 0 \\
\hline Symptoms, signs and abnormal clinical and laboratory findings, not elsewhere classified & 8 & 17 & 12 & 37 \\
\hline Injury, poisoning and certain other consequences of external causes & 20 & 25 & 19 & 64 \\
\hline External causes of morbidity and mortality & 0 & 0 & 1 & 1 \\
\hline Total & 91 & 181 & 144 & 416 \\
\hline
\end{tabular}

1stApril 2016 - March 2017, ${ }^{\text {2ndApril }} 2017$ - March 2018, ${ }^{\text {IrdApril }} 2018$ - March 2019 
group was chickenpox 23 cases, diseases of the digestive system $49(11.78 \%)$ cases. The majority of diseases of the digestive system were dental caries ( 23 cases). Symptoms, signs and abnormal clinical and laboratory findings not elsewhere classified 37 (8.89\%) cases, of which the majority was fever, unspecified 12 cases. By diagnoses after Medevac, we found that diseases of the digestive system increased by 2 cases, diseases of the respiratory system increased by 1 case, diseases of the circulatory system increased by 1 case, diseases of the genitourinary system increased by 1 case, injury, poisoning and certain other consequences of external causes increased by 1 case, congenital malformations, deformations, and chromosomal abnormalities increased by 1 case, diseases of the musculoskeletal system and connective tissue decreased by 1 case and increased by 1 case, symptoms, signs and abnormal clinical and laboratory findings, not elsewhere classified decreased by 5 cases, diseases of the nervous system decreased by 1 case, and diseases of the eye and adnexa

Table 4. Reasons for Medevacs (illness or injury and preventable or unpreventable)

\begin{tabular}{lll}
\hline Reasons for Medevacs & Number & Per cent \\
\hline IIIness or injury & & \\
IIIness & 350 & $84.1 \%$ \\
Injury & 66 & $15.87 \%$ \\
Preventable or unpreventable & & \\
Unpreventable & 250 & $60.10 \%$ \\
Preventable & 166 & $39.90 \%$
\end{tabular}

decreased by 1 case. There were no diving injuries during this 36 -months period.

Next, we classified reasons for Medevacs as injury or illness, and preventable or unpreventable or difficult to prevent, and showed in Table 4. We found that most of the reasons were illness in $350(84.13 \%)$ cases. Then, we analysed it together with age group and found that in every age group, illness was more common than injury. The highest proportion of illnesses was found in over 59-year-old group (100\%), followed by 50 to 59 years ( $86.36 \%), 30$ to 39 years (85.2\%), 40 to 49 years $(82.64 \%)$, and less than 30 years $(80 \%)$, respectively. Older workers were evacuated due to illness more than younger workers and younger workers were evacuated due to injury more than older workers, as noted in Figure 1. Regarding the preventability, the majority of the causes of Medevac were unpreventable/difficult to prevent ( 250 cases, $60.1 \%$ ) and the minority were preventable (192 cases, 39.9\%). Then, we analysed it together with the estimated cost of evacuation and found that the cost of those preventable were $17,160,000 \mathrm{THB}$, and the cost of those unpreventable/difficult to prevent were 19,755,000 THB.

\section{COSTS FOR MEDEVACS IN THE GULF OF THAILAND}

In this study, costs of Medevacs depended on the mode of evacuation, flight time, dedicated chopper and medical escort, and are shown in Table 5. The majority of the mode of movement was helicopter (361 cases, $86.78 \%$ ) and boat (55 cases, 13.22\%). Regarding flight time, 356 (85.58\%) cases were day flight. About $79 \%$ of Medevacs were not dedicated chopper, and $89.42 \%$ were unescorted.

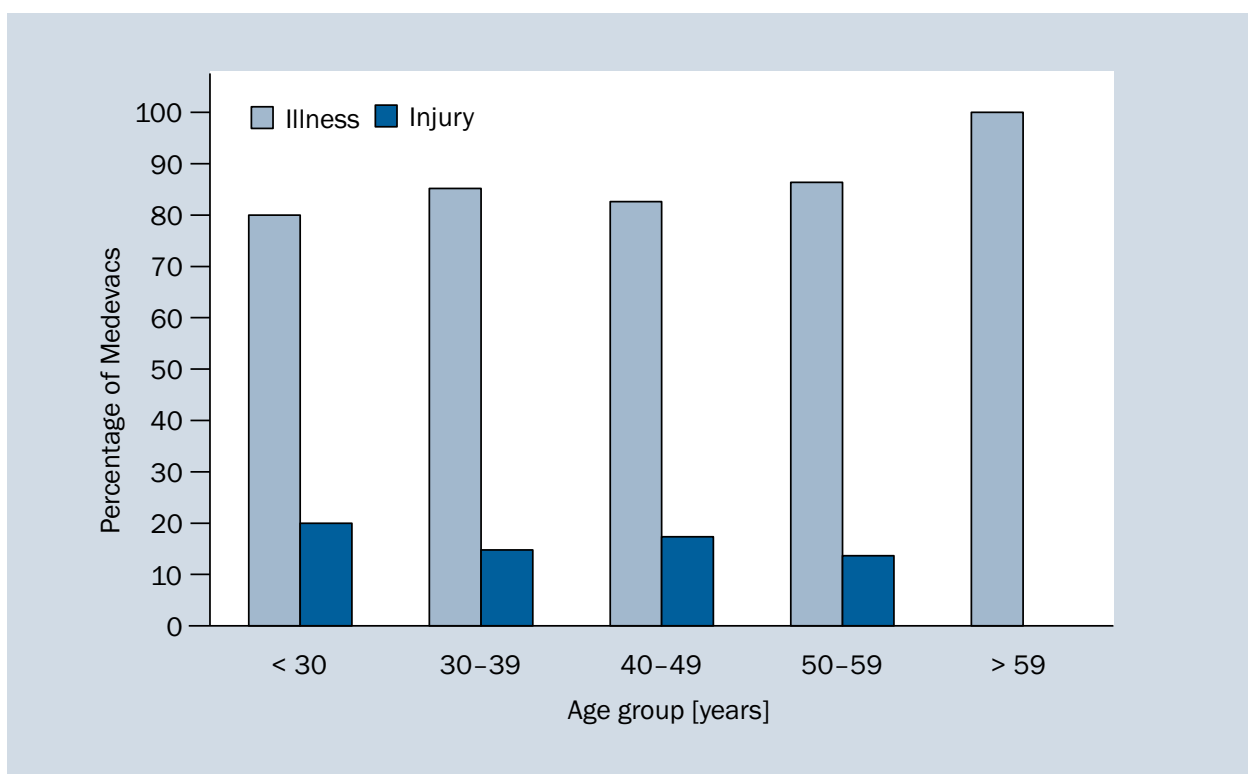

Figure 1. Medevacs by age group and type (illness or injury) 
Table 5. Cost of Medevacs details

\begin{tabular}{lll}
\hline Cost of Medevacs details & $\begin{array}{l}\text { Number and per cent } \\
\text { of Medevacs }\end{array}$ \\
\hline Mode of movement & 361 & $86.78 \%$ \\
Helicopter & 55 & $13.22 \%$ \\
Boat & & \\
Flight time & 356 & $85.58 \%$ \\
Day flight & 5 & $1.20 \%$ \\
Night flight & 55 & $13.22 \%$ \\
Not applicable & 32 & $7.69 \%$ \\
Dedicated chopper & 329 & $79.09 \%$ \\
Yes & 55 & $13.22 \%$ \\
No & & \\
Not applicable & 372 & $89.42 \%$ \\
Medical escort & 32 & $7.69 \%$ \\
Unescorted & 7 & $1.68 \%$ \\
1 nurse & 3 & $0.72 \%$ \\
2 nurses & 2 & $0.48 \%$ \\
1 doctor, 1 nurse & 3 doctor, 2 nurses &
\end{tabular}

Tables 6 and 7 show cost estimates for medical evacuation from the Gulf of Thailand, which were between 10,000 and 880,000 THB. $76.20 \%$ of all Medevacs costed 50,000 THB each. If evacuation by boat, the cost per seat is 10,000 THB. But if evacuated by helicopter, the cost will

Table 6. Cost estimates of Medevacs from the Gulf of Thailand details

\begin{tabular}{lll}
\hline Mode of movement & \multicolumn{2}{l}{ Flight time } \\
\cline { 2 - 3 } & $\begin{array}{l}\text { Day flight } \\
\text { (Thai Baht) }\end{array}$ & $\begin{array}{l}\text { Night flight } \\
\text { (Thai Baht) }\end{array}$ \\
\hline Crew boat (one seat) & 10,000 & 10,000 \\
Helicopter (one seat) for passenger & 50,000 & NA \\
Helicopter (one seat) for escort nurse & 50,000 & NA \\
Helicopter (dedicated flight) & 500,000 & 800,000 \\
1 escort nurse and equipment & 30,000 & 50,000 \\
2 escort nurses with equipment & 50,000 & 80,000 \\
1 escort doctor and 1 escort & 65,000 & 85,000 \\
nurse with equipment & & \\
1 escort doctor and 2 escort & 75,000 & 95,000 \\
nurses with equipment & & \\
\hline NA - not available & &
\end{tabular}

Table 7. Cost estimates for Medevacs from the Gulf of Thailand

\begin{tabular}{|c|c|c|c|c|c|c|c|c|c|}
\hline \multirow{3}{*}{$\begin{array}{l}\text { Mode of } \\
\text { movement }\end{array}$} & & \multirow{2}{*}{\multicolumn{2}{|c|}{$\begin{array}{l}\text { Total cost rate } \\
\text { (Thai Baht) }\end{array}$}} & \multicolumn{5}{|c|}{ Number of Medevacs by medical escort } & \multirow[t]{3}{*}{ Total } \\
\hline & & & & Unescorted & 1 nurse & 2 nurses & $\begin{array}{l}1 \text { doctor } \\
\text { and } 1 \text { nurse }\end{array}$ & $\begin{array}{l}1 \text { doctor } \\
\text { and } 2 \text { nurses }\end{array}$ & \\
\hline & & $\begin{array}{l}\text { Time of } \\
\text { movement }\end{array}$ & $\begin{array}{l}\text { Day time } \\
\text { Night-time }\end{array}$ & $\begin{array}{l}0 \\
0\end{array}$ & $\begin{array}{l}30,000 \\
50,000\end{array}$ & $\begin{array}{l}50,000 \\
80,000\end{array}$ & $\begin{array}{l}65,000 \\
85,000\end{array}$ & $\begin{array}{l}75,000 \\
95,000\end{array}$ & \\
\hline \multirow{2}{*}{\multicolumn{2}{|c|}{ Boat }} & \multicolumn{2}{|l|}{10,000} & 55 & - & - & - & - & 55 \\
\hline & & \multicolumn{2}{|l|}{50,000} & 317 & - & - & - & - & 317 \\
\hline \multirow{2}{*}{\multicolumn{2}{|c|}{ Helicopter }} & \multicolumn{2}{|c|}{$\begin{array}{l}130,000 \\
(50,000+50,000+30,000)\end{array}$} & - & 12 & - & - & - & 12 \\
\hline & & \multicolumn{2}{|c|}{$\begin{array}{l}530,000 \\
(500,000+30,000)\end{array}$} & - & 17 & - & - & - & 17 \\
\hline \multirow{5}{*}{ 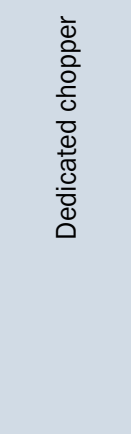 } & & \multicolumn{2}{|c|}{$\begin{array}{l}550,000 \\
(500,000+50,000)\end{array}$} & - & - & 5 & - & - & 5 \\
\hline & & \multicolumn{2}{|c|}{$\begin{array}{l}565,000 \\
(500,000+65,000)\end{array}$} & - & - & - & 3 & - & 3 \\
\hline & & \multicolumn{2}{|c|}{$\begin{array}{l}575,000 \\
(500,000+75,000)\end{array}$} & - & - & - & - & 2 & 2 \\
\hline & $\stackrel{\overrightarrow{\underline{c}}}{\underline{\underline{\underline{p}}}}$ & \multicolumn{2}{|c|}{$\begin{array}{l}850,000 \\
(800,000+50,000)\end{array}$} & - & 3 & - & - & - & 3 \\
\hline & $\frac{+}{\frac{20}{20}}$ & \multicolumn{2}{|c|}{$\begin{array}{l}880,000 \\
(800,000+80,000)\end{array}$} & - & - & 2 & - & - & 2 \\
\hline \multicolumn{4}{|l|}{ Total } & 372 & 32 & 7 & 3 & 2 & 416 \\
\hline
\end{tabular}


start at 50,000 THB per seat. Also, dedicated flight started at 500,000 THB for day flights and 800,000 THB for night flights. As for the medical escort team, if one nurse is needed in evacuation by a helicopter, it will normally cost an additional 50,000 THB for the nurse's seat. If it is a dedicated flight, there will be an additional cost for 1 nurse with equipment equal to $30,000 \mathrm{THB}$ for day flights and 50,000 THB for night flights. The cost for 2 nurses with equipment is 50,000 THB for day flights and 80,000 THB for night flights. The cost for 1 doctor and 1 nurse with equipment is 65,000 THB for day flights and 85,000 THB for night flights. The cost for 1 doctor and 2 nurses with equipment is 75,000 THB for day flights and 95,000 THB for night flights.

\section{EMERGENCY MEDEVACS IN THE GULF OF THAILAND}

During the study period, 38 patients were emergency disembarking and 7 patients were high cost due to dedicated flight, a total of 45 cases. All evacuees were male, between the ages of 22 to 60 years, the mean age being 40.33 years. Most of them (37 patients, $82.22 \%$ ) were Thai. Regarding type of employment, 22 (48.89\%) evacuees were direct employee. Regarding injury or illness, 28 (62.22\%) evacuees were illnesses. The top 4 causes of emergency Medevacs in the Gulf of Thailand were group of Injury, poisoning and certain other consequences of external causes (17 cases, $37.78 \%$ ) with 7 cases of lower limb injuries ( $77.78 \%$ of injury groups). Nine $(20.00 \%)$ cases were diseases of the digestive system. About $78 \%$ of diseases of the digestive system were acute appendicitis ( 7 cases, $15.56 \%$ of all Medevacs). Five cases were diseases of the circulatory system (11.11\%). Four of the diseases of the circulatory system were acute coronary syndrome, accounting for $8.89 \%$ of all Medevacs. Four (8.89\%) cases were diseases of the nervous system. Two cases were epilepsy and 2 cases were acute stroke, respectively, as shown in Table 8.

\section{DISCUSSION}

The purpose of this study was to explore the causes and costs of medical evacuation among offshore oil and gas industry worker in the Gulf of Thailand. We reviewed the previous medical record during April 2016 and March 2019 (36 months) which obtained from companies that consent to disclose information.

The majority (84.13\%) of the causes of Medevac were illness, in line with previous studies in the North Sea from 1976 to 1984 with 2,162 Medevacs. They found that after the 1980s, the proportion of illness increased in contrast to the decrease of injuries [5]. Later, Health and Safety Executive conducted a study in the North Sea from 1987 to 1992, and found that there were 3,979 Medevacs, of which
$55 \%$ were illnesses and $45 \%$ were injuries. Of note is that in the last year of the study, illness increased to $65 \%$ of all Medevacs. This was a result of increased safety management and the transition from exploration and construction to operation and maintenance [6]. Thibodaux et al. [7] reported that $77 \%$ of all Medevacs were due to medical reasons, and $23 \%$ due to occupational reasons [7]. Toner et al. [8] found that $80 \%$ of Medevacs were caused by illness and $20 \%$ by injury.

The top 8 causes of Medevacs in the Gulf of Thailand were influenza $20.19 \%$, injury and wound $7.45 \%$, chickenpox $5.53 \%$, fracture, dislocation, sprain, and strain $4.09 \%$, urolithiasis $3.85 \%$, dental caries $3.13 \%$, acute appendicitis $2.88 \%$, and low back pain $2.88 \%$, respectively. While previous studies on Medevacs in the offshore oil and gas industry revealed that the most common causes of Medevacs were gastrointestinal diseases, especially dental problems and abdominal pain, cardiovascular disease, especially myocardial infarction, diseases of the nervous system including seizures, diseases of the musculoskeletal system and injuries, respectively [3, 5, 7-10].

Regarding age of evacuees, we found that older workers were evacuated due to illness more than younger workers and younger workers were evacuated due to injury more than the older workers. This is consistent with most studies in foreign countries, such as the Norman et al. [5] study found that the age increase in the proportion of causes due to injury decreased but the illness increased. In December 2012, United Kingdom report on oil stations injuries in the North Sea indicated that $60.9 \%$ of these injuries are in those aged 25 to 49 years and those between the age of 30 and 34 years have the highest incidence rate at $15.8 \%$ [11]. Greuters et al. [10] studied the medical records of 115 patients who were repatriated by plane between 1998 and 2002. Those patients were divided into two groups: younger than 50 years $(n=38)$ and 50 years and older $(n=77)$. In the younger group, $32 \%$ were repatriated due to traumatic fractures. While $52 \%$ of the older group were repatriated due to cardiopulmonary disease [10]. Thibodaux et al. [7] found that younger workers were Medevacs due to occupational injuries more than older workers and medical conditions were the main cause of Medevacs among older workers [7].

In terms of work-relatedness, our study found that $89 \%$ of Medevacs were not work-related. This is in consistent with Thibodaux et al. [7] that $77 \%$ of all Medevacs were caused by non-occupational medical injury or illness.

There were 2 death cases in this 3-year study period, one cardiac arrest and one intracerebral haemorrhage.

We define "preventable" as prevention of Medevacs and/or reduction of emergency Medevacs are possible. This can be achieved by:

- Vaccination for vaccine-preventable diseases; 
Table 8. Reasons and costs of emergency Medevacs from the Gulf of Thailand

\begin{tabular}{|c|c|c|c|c|c|c|c|}
\hline $\begin{array}{l}\text { Mode of } \\
\text { movement }\end{array}$ & $\begin{array}{l}\text { Total } \\
\text { cost rate } \\
\text { (THB) }\end{array}$ & Reasons for Medevacs & $\begin{array}{l}\text { Age } \\
\text { [years] }\end{array}$ & Nationality & $\begin{array}{l}\text { Type of } \\
\text { employment }\end{array}$ & $\begin{array}{l}\text { Incident } \\
\text { month }\end{array}$ & $\begin{array}{l}\text { Incident } \\
\text { year }\end{array}$ \\
\hline ED & 880,000 & NSTEMI & 42 & Thai & Direct employee & January & 2018 \\
\hline ED & 880,000 & Unspecified injury of thorax & 32 & Thai & Direct employee & July & 2016 \\
\hline ED & 850,000 & ACS & 53 & Indonesian & Direct employee & September & 2016 \\
\hline ED & 850,000 & Unspecified acute appendicitis. & 38 & Indonesian & Subcontractor & October & 2017 \\
\hline ED & 575,000 & NSTEMI & 42 & Thai & Subcontractor & August & 2018 \\
\hline ED & 575,000 & Dislocation of right shoulder joint & 40 & Thai & Subcontractor & December & 2018 \\
\hline ED & 565,000 & Cerebellar stroke syndrome & 33 & Thai & Subcontractor & May & 2018 \\
\hline ED & 565,000 & ACS & 41 & Thai & Subcontractor & December & 2018 \\
\hline ED & 565,000 & $\begin{array}{l}\text { Local infection of the skin and } \\
\text { subcutaneous tissue, unspecified }\end{array}$ & 46 & Thai & Direct employee & December & 2018 \\
\hline ED & 560,000 & $\begin{array}{l}\text { Unspecified injury to unspecified } \\
\text { level of lumbar spinal cord }\end{array}$ & 27 & Thai & Others & April & 2017 \\
\hline ED & 560,000 & Epilepsy & 41 & Thai & Direct employee & May & 2016 \\
\hline ED & 550,000 & Unspecified injury of head & 42 & Thai & Subcontractor & October & 2017 \\
\hline ED & 530,000 & $\begin{array}{l}\text { Unspecified fracture of right foot, } \\
\text { initial encounter for closed fracture }\end{array}$ & 46 & Thai & Direct employee & January & 2019 \\
\hline ED & 530,000 & Cerebellar stroke syndrome & 50 & Thai & Direct employee & February & 2019 \\
\hline ED & 530,000 & Unspecified acute appendicitis & 31 & Thai & Direct employee & March & 2017 \\
\hline ED & 530,000 & $\begin{array}{l}\text { Other intestinal obstruction } \\
\text { unspecified as to partial versus } \\
\text { complete obstruction }\end{array}$ & 42 & Canadian & Direct employee & March & 2018 \\
\hline ED & 530,000 & Traumatic pneumothorax & 22 & Myanmaese & Others & May & 2018 \\
\hline ED & 530,000 & Low back pain & 40 & Thai & Direct employee & June & 2017 \\
\hline ED & 530,000 & Chest pain, unspecified & 47 & Thai & Subcontractor & June & 2018 \\
\hline ED & 530,000 & $\begin{array}{l}\text { Pain localised to other parts of } \\
\text { lower abdomen }\end{array}$ & 59 & Malaysian & Subcontractor & June & 2018 \\
\hline ED & 530,000 & Unspecified acute appendicitis & 38 & Thai & Subcontractor & July & 2017 \\
\hline ED & 530,000 & Pneumonia, unspecified organism & 47 & Thai & Direct employee & July & 2017 \\
\hline ED & 530,000 & Gastritis, unspecified, with bleeding & 40 & Thai & Direct employee & September & 2018 \\
\hline ED & 530,000 & Traumatic pneumothorax & 42 & Laotian & Others & September & 2018 \\
\hline ED & 530,000 & Unspecified acute appendicitis & 32 & Thai & Subcontractor & November & 2017 \\
\hline ED & 130,000 & Atrioventricular block, second degree & 42 & Thai & Direct employee & March & 2017 \\
\hline ED & 130,000 & Unspecified acute appendicitis & 54 & Australian & Direct employee & March & 2017 \\
\hline ED & 130,000 & Epilepsy & 41 & Thai & Subcontractor & April & 2018 \\
\hline ED & 130,000 & Schizophrenia, unspecified & 39 & Thai & Direct employee & April & 2018 \\
\hline ED & 130,000 & Fracture of lower end of femur & 31 & Thai & Direct employee & June & 2017 \\
\hline ED & 130,000 & Unspecified acute appendicitis & 29 & Thai & Direct employee & November & 2016 \\
\hline ED & 50,000 & Other peripheral vertigo, unspecified ear & 60 & Thai & Subcontractor & February & 2017 \\
\hline ED & 50,000 & $\begin{array}{l}\text { Burn of cornea and conjunctival sac, } \\
\text { left eye, sequela }\end{array}$ & 37 & Thai & Direct employee & March & 2017 \\
\hline
\end{tabular}


Table 8 cont. Reasons and costs of emergency Medevacs from the Gulf of Thailand

\begin{tabular}{|c|c|c|c|c|c|c|c|}
\hline $\begin{array}{l}\text { Mode of } \\
\text { movement }\end{array}$ & $\begin{array}{l}\text { Total } \\
\text { cost rate } \\
(\mathrm{THB})\end{array}$ & Reasons for Medevacs & $\begin{array}{l}\text { Age } \\
\text { [years] }\end{array}$ & Nationality & $\begin{array}{l}\text { Type of } \\
\text { employment }\end{array}$ & $\begin{array}{l}\text { Incident } \\
\text { month }\end{array}$ & $\begin{array}{l}\text { Incident } \\
\text { year }\end{array}$ \\
\hline ED & 50,000 & $\begin{array}{l}\text { Displaced fracture of distal phalanx } \\
\text { of right middle finger, initial encounter } \\
\text { for open fracture }\end{array}$ & 41 & Thai & Direct employee & May & 2016 \\
\hline ED & 50,000 & Unspecified acute appendicitis & 34 & Thai & Subcontractor & June & 2018 \\
\hline ED & 50,000 & Crushing injury of right ring finger & 27 & Malaysian & Subcontractor & August & 2017 \\
\hline ED & 50,000 & $\begin{array}{l}\text { Crushing injury of right foot, initial } \\
\text { encounter }\end{array}$ & 35 & Thai & Direct employee & September & 2016 \\
\hline ED & 10,000 & $\begin{array}{l}\text { Unspecified asthma with (acute) } \\
\text { exacerbation }\end{array}$ & 56 & Thai & Subcontractor & December & 2016 \\
\hline NED & 850,000 & $\begin{array}{l}\text { Unspecified fracture of right lower leg, } \\
\text { initial encounter for closed fracture }\end{array}$ & 45 & Thai & Subcontractor & March & 2017 \\
\hline NED & 560,000 & $\begin{array}{l}\text { Unspecified fracture of right lower leg, } \\
\text { initial encounter for closed fracture }\end{array}$ & 29 & Thai & Direct employee & September & 2016 \\
\hline NED & 560,000 & Anxiety disorder, unspecified & 24 & Thai & Subcontractor & September & 2017 \\
\hline NED & 530,000 & $\begin{array}{l}\text { Unspecified injury of left foot, initial } \\
\text { encounter }\end{array}$ & 47 & Thai & Subcontractor & May & 2017 \\
\hline NED & 530,000 & Cellulitis of right lower limb & 58 & Thai & Subcontractor & June & 2018 \\
\hline NED & 530,000 & $\begin{array}{l}\text { Displaced fracture of lateral malleolus } \\
\text { of left fibula, initial encounter for } \\
\text { closed fracture }\end{array}$ & 42 & Thai & Direct employee & November & 2017 \\
\hline $\begin{array}{l}\text { Medical } \\
\text { referral }\end{array}$ & 530,000 & $\begin{array}{l}\text { Strain of muscle, fascia and tendon of } \\
\text { lower back, subsequent encounter }\end{array}$ & 31 & Thai & Subcontractor & April & 2017 \\
\hline
\end{tabular}

ACS - acute coronary syndrome; ED - emergency disembarking, NED - non-emergency disembarking; NSTEMI - non-ST segment elevation myocardial infarction

- Screening to prevent people at risk of complications of underlying diseases from going to work offshore; or keeping their underlying diseases in good control while they are offshore. Examples of this approach are appropriate dental examination and treatment, appropriate fitness for work examination (such as non-communicable diseases) before allowing the workers go offshore, more than adequate individual medication (in case of longer offshore stay/work), etc.;

- Increasing the treatment capability of offshore facility, such as more sophisticated medical equipment and medications, more competent medical personnel, and more consultation via telemedicine. This approach may reduce Medevacs or postpone the time to evacuate from emergency to normal. However, this may be costly and not cost-effective.

We also define "unpreventable" as non-vaccine-preventable diseases, and those with no effective screening, such as fracture or severe injury.

And we define "difficult to prevent" as prevention of Medevacs is possible but costly, such as acute appendicitis or severe injury which are beyond usual offshore treatment capability. Establishing an offshore surgery is possible but will cost more than referring patients to a more-equipped onshore facility.

When dividing the preventable causes into three groups mentioned above, we found that 126 patients were in group 1 : influenza, chickenpox, zoster, and mumps. Group 2 included 58 patients: acute coronary syndrome, urolithiasis, acute stroke, dental problems, hypertension, type 2 diabetes mellitus, gout, hernia, psychiatric disorders, asthma with acute exacerbation and gallstone. Group 3 included 66 patients: pain in extremities (any part), myalgia, skin infection, low back pain, acute conjunctivitis, acute gastroenteritis, acute upper respiratory infection, dermatitis, allergic reaction, dengue fever, chikungunya virus disease, dizziness, urticaria, urinary tract infection, impacted cerumen, folliculitis, functional dyspepsia, gastritis, and gastro-oesophageal reflux disease.

Over the 3-year study period, the preventable cause was established in 192 (39.9\%) cases and costs of Medevacs for these preventable causes were 17,160,000 THB. About $50 \%$ of the preventable causes were in group 1 , which can be prevented by vaccination, including influenza. Eighty-four 
cases of influenza were 41 direct employees and 43 subcontractors. The company may vaccinate direct employees, but the subcontractors may not be vaccinated, causing the spread of the disease. The costs of influenza-caused Medevacs were $3,450,000$ THB. If each influenza vaccination cost $500 \mathrm{THB}$, we will be able to vaccinate up to 6,900 people with this amount of money.

In Thailand, companies have medical screening for health based on the United Kingdom Oil and Gas Industry Association Limited, trading as OGUK, standard and company standard which aligned with International Association of Oil and Gas Producers. There is not a code of practice; evacuation guideline is developed by each company. They have tried to develop a national guideline but no agreement among companies since they are also competitors.

They have employee wellness programmes. Non-occupational health risk is identified individually. Those with high risk and/or high consequence are focused and monitored continuously. Those with identified risk will be enrolled to appropriate health program accordingly, such as smoke cessation, exercise, weight reduction, diet control/restriction, lifestyle modification, etc.

Pre-placement examination and periodic examination, including health promotion and disease prevention programmes can reduce the severity of the disease and prevent the emergency Medevacs. Non-communicable diseases, such as diabetes mellitus, hypertension, cardiovascular and cerebrovascular diseases, caused high cost of Medevacs. For instance, there were only 4 patients evacuated with acute coronary syndrome, but the costs of Medevacs were up to 2,870,000 THB. Only 2 acute stroke patients costed up to $1,095,000$ THB. Hypertension and diabetes mellitus costed 380,000 THB. Dental problems costed 720,000 THB. With appropriate dental examination and treatment, this cost could be reduced or avoided.

In group 3, pain in extremities (any part), myalgia, and low back pain costed up to $1,380,000$ THB. Skin infection costed 725,000 THB. Acute conjunctivitis costed 450,000 THB. Functional dyspepsia, gastritis, and gastro-oesophageal reflux disease costed 360,000 THB. If these diseases can be treated offshore, the cost of Medevacs could be avoided.

\section{LIMITATIONS OF THIS STUDY}

This study is a retrospective descriptive study; therefore, only recorded data can be retrieved. We could not get some useful information such as patients' underlying diseases and job type data, so we did not have them. It is the limitation of this kind of secondary data. Moreover, some of the information received is incomplete, such as the final diag- nosis. We did not know the majority of the final diagnoses because the company did not follow up nor record.

We obtained secondary data only from companies that have agreed to disclose information. Some companies do not consent to disclose this information, causing us not to obtain data from every company in the oil and gas industry in the Gulf of Thailand.

\section{CONCLUSIONS}

Medical evacuations among oil and gas industry workers in the Gulf of Thailand are very costly. The major causes of medical evacuations are illnesses. Reducing the cost of Medevac can be done by: 1) giving vaccines to prevent vaccine-preventable diseases, 2) screening to prevent people at risk of getting complications from pre-existing diseases to work offshore, and 3 ) increasing treatment capability of offshore facilities. Offshore oil and gas industry may consider cost-benefit of these approaches compared to status quo.

\section{REFERENCES}

1. Klaewkla C, Vongvanich $P$, Sujiratana A, et al. Maritime Medicine Naval Medical Department. (in Thai). Nonthaburi: Sahamitr Printing \& Publishing. 2014.

2. Cox R. Medical services to offshore drilling. Injury. 1970; 1(3): 217-225, doi: 10.1016/s0020-1383(70)80058-4.

3. Ponsonby W, Mika F, Irons G. Offshore industry: medical emergency response in the offshore oil and gas industry. Occup Med (Lond). 2009; 59(5): 298-303, doi: 10.1093/occmed/kqp075, indexed in Pubmed: 19608660.

4. World Health Organization. ICD-10 Version: 2016. https://icd.who. int/browse10/2016/en (cited 2019 Apr 18).

5. Norman JN, Ballantine BN, Brebner JA, et al. Medical evacuations from offshore structures. Br J Ind Med. 1988; 45(9): 619-623, doi: 10.1136/oem.45.9.619, indexed in Pubmed: 3179237.

6. Health \& Safety Executive. Study of Medical Evacuations from offshore installations 1987-1992 1999. https://www.hse.gov.uk/ research/otopdf/1998/oto98171.pdf (cited 2020 Feb 14).

7. Thibodaux DP, Bourgeois RM, Loeppke RR, et al. Medical evacuations from oil rigs off the Gulf Coast of the United States from 2008 to 2012: reasons and cost implications. J Occup Environ Med. 2014; 56(7): 681-685, doi: 10.1097/J0M.0000000000000221, indexed in Pubmed: 24988094.

8. Toner S, Andrée Wiltens DH, Berg J, et al. Medical evacuations in the oil and gas industry: a retrospective review with implications for future evacuation and preventative strategies. J Travel Med. 2017; 24(3), doi: 10.1093/jtm/taw095, indexed in Pubmed: 28355616.

9. Duffy B. Dental problems in the offshore oil and gas industry: a review. Occup Med (Lond). 1996; 46(1): 79-83, doi: 10.1093/ occmed/46.1.79, indexed in Pubmed: 8672801.

10. Greuters S, Christiaans HMT, Veenings B, et al. Evaluation of repatriation parameters: does medical history matter? J Travel Med. 2009; 16(1): 1-6, doi: 10.1111/j.1708-8305.2008.00253.x, indexed in Pubmed: 19192120.

11. Health \& Safety Executive. Offshore injury, ill health and incident statistics 2011/2012 2012. http://www.hse.gov.uk/offshore/ statistics/hsr1112.pdf (cited 2018 Nov 5). 